\section{GENTRIFICACIÓN, DESPLAZAMIENTO, DESPOSESIÓN: PROCESOS URBANOS CLAVES EN AMÉRICA LATINA*}

Michael Janoschka**

\section{GENTRIFICATION- DISPLACEMENT- DISPOSSESSION: KEY URBAN PROCESSES IN LATIN AMERICAN CITIES*}

Michael Janoschka**

\section{Resumen}

Este artículo aporta una comprensión pormenorizada de los procesos urbanos claves que se han ido perpetuando en las ciudades latinoamericanas durante los primeros tres lustros del siglo XXI y que consisten en la reconquista de las áreas centrales y peri-centrales por parte del capital inmobiliario. Esta metamorfosis de la ciudad consolidada se ha manifestado a partir del uso habitual de tres términos centrales: gentrificación, desplazamiento y desposesión. Basándose en una conceptualización del desplazamiento como proceso material, político, simbólico y psicológico, se irá fomentando una comprensión teórica de los procesos que conllevan al desplazamiento de las subjetividades

\section{Abstract}

This article offers a detailed analysis of key urban processes that have been consolidated in different Latin American cities over the XXI century; they fundamentally consist of a reconquest of central and peri-central areas by real estate capital. The metamorphosis of the consolidated city has become apparent thanks to the regular use of three central terms: gentrification, displacement and dispossession. Through the conceptualization of the notion of displacement as a material, political, symbolic and psychological process, this paper builds a theoretical understanding of the phenomena that 
populares de las áreas centrales y peri-centrales de las ciudades latinoamericanas. A partir de un análisis comparativista desarrollado en cinco ciudades -Ciudad de México, Buenos Aires, Río de Janeiro, Santiago de Chile y Quito- se establece una tipificación de los procesos de desplazamiento y desposesión. Esta discusión permite analizar el significado que tiene la reconfiguración territorial de cara a las injusticias espaciales, así como para los discursos en torno al "Derecho a la Ciudad", aportando por tanto una comprensión política adicional de los procesos urbanos que se consideran claves en las primeras décadas del siglo XXI.

\section{PALABRAS CLAVE: GENTRIFICACIÓN, DESPLAZAMIENTO, DESPOSESIÓN, DERECHO A LA CIUDAD, AMÉRICA LATINA}

Recibido: 08-03-2016

Aceptado: 30-09-2016

* Esta investigación ha sido desarrollada en el marco del proyecto "CONTESTED CITIES: Contested Spatialities of Urban Neoliberalism", financiado por la Comisión Europea (Grant Agreement: FP7-PEOPLE-PIRSES-GA-2012-318944).

** Reino Unido. School of Geography, University of Leeds. Correo electrónico: michael.janoschka@leeds.ac.uk. lead to the displacement of popular subjectivities from the central and peri-central areas of Latin American cities. Such a premise is used to comparatively analyze the situation of five cities -Mexico City, Buenos Aires, Rio de Janeiro, Santiago and Quito- and categorize the different displacement and dispossession processes. This discussion also analyzes the meaning of territorial reconfiguration in relation to spatial injustice and the discourses on the "Right to the City", thus providing a political understanding of the 21st century key urban processes.

\section{KEYWORDS: GENTRIFICATION; DISPLACEMENT; DISPOSSESSION; RIGHT TO THE CITY; LATIN AMERICA}

Received: 08-03-2016

Accepted: 30-09-2016

* This research has been developed in the framework of the project "CONTESTED_CITIES: Contested Spatialities of Urban Neoliberalism", funded by the European Commission (Grant Agreement: FP7-PEOPLE-PIRSES-GA-2012-318944).

** United Kingdom. School of Geography, University of Leeds. Email: michael.janoschka@leeds.ac.uk.

ARTICLE: Gentrification-Displacement-Dispossession: Key Urban Processes in Latin American cities / Michael Janoschka 


\section{Introducción}

Una de las características esenciales de las dinámicas sociales, políticas y espaciales que se han ido perpetuando en las ciudades latinoamericanas durante los primeros tres lustros del siglo XXI consiste en la reconquista de las áreas centrales y peri-centrales por parte del capital inmobiliario. Comparado con el período previo, de aplicación de políticas neoliberales más viral y durante el cual la transformación de la estructura urbana se explicaba principalmente por los efectos de una expansión periférica de carácter centrifugal ${ }^{1}$, la fase contemporánea adquiere rasgos materiales y simbólicos diferentes. Como todo proceso urbano estructural, se enmarca en una modificación de los mecanismos de acumulación. Esta va, mano en mano, con la implementación de políticas urbanas de atracción de inversiones que generan nuevas posibilidades de beneficio mediante el aumento del valor del suelo, habitualmente apropiado por agentes inmobiliarios privados ${ }^{2}$.

Esta metamorfosis de la ciudad consolidada, que se manifiesta a partir de la actividad inmobiliaria, la llegada de nuevos colectivos y su iconografía en el espacio público, tiene ganadores y perdedores. A veces de forma nítida y otras de manera más trascendente, implica el desplazamiento, la expulsión

1 Mattos, 2001; Janoschka, 2002.

2 Cócola, Durán y Janoschka, 2016.

\section{Introduction}

One of the main characteristics of the social, political and spatial dynamics that have been consolidated in Latin American cities over the XXI century refers to the recovery of central and peri-central areas. The comparison between this and the previous period -which witnessed an increase in the implementation of neoliberal policies and the transformation of the urban structure as the result of centrifugal expansion in the peripheral areas of the city ${ }^{1}$ - shows that there is a predominance of different material and symbolic features. As in all urban structural processes, the current phenomenon is marked by the modification of accumulation mechanisms. This goes hand-in-hand with the implementation of urban policies intended to attract investment and generate new benefit opportunities through the increase in the value of land-which is usually owned by private real estate agents ${ }^{2}$.

The metamorphosis of the consolidated city which has become apparent thanks to real estate activity, the arrival of new groups and their iconography in public space- has winners and losers. This sometimes visible and significant

$1 \quad$ Mattos, 2001; Janoschka, 2002.

2 Cócola, Durán and Janoschka, 2016. 
y la exclusión de habitantes con bajo poder adquisitivo ya que estos, al igual que sus prácticas cotidianas, suponen una barrera para la extracción de rentas de suelo. Si bien en este contexto el uso de los términos "gentrificación", "desplazamiento" o "desposesión" se ha difundido de forma creciente para caracterizar los cambios ${ }^{3}$, sigue habiendo lagunas importantes. Esto es especialmente el caso en la comprensión conceptual y teórica de las dinámicas de desplazamiento. Cabe señalar que aunque el desplazamiento es intrínseco a las ciudades capitalistas y determinante para la vida de los habitantes de menores recursos, es uno de los procesos estructurales que menos atención ha recibido en los estudios urbanos ${ }^{4}$.

Por ende, este artículo pretende aportar una comprensión pormenorizada de la relación entre los procesos de gentrificación, desplazamiento y desposesión que se desarrolla en tres pasos. En primer lugar, se irán acotando perspectivas conceptuales sobre el desplazamiento que tengan en cuenta tanto los efectos materiales-económicos como las dimensiones simbólicas, las prácticas discursivas y las consecuencias psicológicas que surjan por las múltiples violencias (físicas y simbólicas) que se ejercen durante los procesos de gentrificación. En

3 Casgrain y Janoschka, 2013; Inzulza, 2014; Janoschka, Sequera y Salinas, 2014.

4 Desmond, 2012. phenomenon implies the displacement, eviction and exclusion of dwellers with low purchasing power since they -and their daily activitiessuppose a barrier to the extraction of ground rents. While in this context the terms "gentrification", "displacement" and "dispossession" are increasingly used to refer to these changes", there are still some important gaps. Such is the case of the conceptual and theoretical understanding of displacement dynamics. It is worth mentioning that despite displacement is inherent to capitalist cities and determines the lives of lower-income people, this structural process has received only limited attention by urban researchers ${ }^{4}$.

This is why this research aims at providing a detailed understanding of the relationship among gentrification, displacement and dispossession. Such an analysis is divided into three steps; firstly, this paper identifies different conceptual perspectives about displacement that include the symbolic dimensions, the discursive practices and the material-economic and psychological consequences of the (physical and symbolic) violence inflicted during gentrification processes. Then, the article offers a comparativist analysis

3 Casgrain and Janoschka, 2013; Inzulza, 2014; Janoschka, Sequera and Salinas, 2014

4 Desmond, 2012. 
un segundo paso, se usará el análisis comparativista desarrollado en cinco ciudades -Ciudad de México, Buenos Aires, Rio de Janeiro, Santiago de Chile y Quito- para detallar una tipificación de los procesos de desplazamiento. Finalmente, se irá analizando el significado que tiene la reconfiguración territorial de cara a las injusticias espaciales, así como para los discursos en torno al "Derecho a la Ciudad", aportando por tanto una comprensión política adicional de los procesos urbanos que se consideran claves en las primeras décadas del siglo XXI.

El análisis se basa en investigaciones empíricas que se llevaron a cabo entre 2012 y 2016 en las cinco ciudades mencionadas anteriormente. El trabajo de campo comprendió la aplicación de diferentes métodos de índole cualitativa, como entrevistas a expertos, observación participante, derivas temáticas, entrevistas narrativas e investigación-acción participativa. Siendo las ciudades analizadas ejemplos paradigmáticos, icónicos y a la vez divergentes, el análisis sostiene un avance en la construcción -todavía incipiente- de una comprensión comparativista ${ }^{5}$ de las tendencias urbanas recientes en América Latina. Esto implica metodológicamente entender las experiencias empíricas comparativas como punto de partida para efectuar una abstracción teórica que sirve para inspirar las reflexiones conceptuales.

5 Para mayor detalle en relación a los debates contemporáneos acerca de la perspectiva comparativista en los estudios urbanos, véase McFarlane, 2010; Peck, 2015; Robinson, 2016; Waley, 2016. of five cities -Mexico City, Buenos Aires, Rio de Janeiro, Santiago and Quito- in order to categorize the different displacement processes. Finally, there is an analysis of the meaning of territorial reconfiguration within the context of spatial injustice and the discourses on the "Right to the City", thus providing a political understanding of current key urban processes.

The analysis is based on empirical research conducted in the above mentioned cities between 2012 and 2016. Field work involved the implementation of different qualitative methods, interviews with experts, participant observation, thematic derivation, narrative interviews and participatory research-action. Since the cities analyzed are paradigmatic, iconic and divergent examples, it is argued that there is some-incipient-progress in the elaboration of a comparativist understanding of current urban tendencies in Latin America ${ }^{5}$. This implies an understanding of the comparative empirical experiences as a starting point to elaborate theoretical abstractions and conceptual reflections.

5 For further information regarding the contemporary debate on the comparative understanding of urban studies, please refer to McFarlane, 2010; Peck, 2015; Robinson, 2016; Waley, 2016. 


\section{Gentrificación, desplazamiento, desposesión: un cuadro analítico y conceptual}

A raíz de evidencia empírica, los debates académicos han confirmado la pertinencia de aplicar el concepto de gentrificación para caracterizar las amplias reconfiguraciones sociales, políticas, económicas y territoriales que se han observado en las áreas centrales y peri-centrales de las grandes ciudades de la región. Numerosos estudios de caso contribuyeron a un amplio análisis 'colectivo' de los mecanismos que provocan la gentrificación ${ }^{6}$. Se ha ido reconociendo que los procesos de gentrificación varían en forma y desarrollo en cada contexto geográfico específico. Esta afirmación se extiende también a los aspectos que diferencian la gentrificación 'latinoamericana' del mundo anglosajón. Si bien los debates fueron exhaustivos en términos de alcance territorial, evitaron ahondar en una comprensión conceptual sistemática de los

6 Para más detalle, véase las obras colectivas editadas por $\mathrm{Hi}$ dalgo y Janoschka, 2014; Delgadillo, Díaz y Salinas, 2015; los números especiales de Revista de Geografía Norte Grande 58 (2014) y Urban Geography (2016); las amplias revisiones bibliográficas desarrolladas por Janoschka, Sequera y Salinas, 2014 y Janoschka y Sequera, 2016; así como artículos de Betancur, 2014; Blanco, Bosoer y Apaolaza, 2014; Inzulza, 2014; Herzer, Di Virgilio y Rodríguez, 2015.

\section{Gentrification, Displacement, Dispossession: An Analytical and Conceptual Framework}

Given the availability of empirical evidence, academic debates have confirmed the relevance of using the concept of gentrification to refer to the social, political, economic and territorial reconfiguration of the central and peri-central areas in large Latin American cities. There are a number of case studies that contributed to the development of a "collective" and comprehensive analysis of gentrifying mechanisms ${ }^{6}$. It has also been acknowledged that gentrification processes may change from one geographic context to another. This is also valid for the aspects that distinguish the 'Latin American' gentrification from the that of the Anglophone world. While there were some important debates on the territorial scope of this phenomenon, it is still lacking a systematic conceptual discussion

$6 \quad$ For further details, please refer to the collective work edited by Hidalgo and Janoschka, 2014; Delgadillo,Díaz and Salinas, 2015; the special issues of Revista Geografía Norte Grande (2014) and Urban Geography (2016); a comprehensive literature review conducted by Janoschka, Sequera and Salinas, 2014 and Janoschka and Sequera, 2016; and research conducted by Betancur, 2014; Blanco, Bosoer and Apaolaza, 2014; Inzulza, 2014; Herzer, Di Virgilio and Rodríguez, 2015. 
procesos de desplazamiento y desposesión que la gentrificación implica para las clases populares.

La gentrificación consiste en un proceso territorial que es el resultado de ensamblajes económicos y políticos específicos y que provoca procesos de acumulación por desposesión mediante el desplazamiento y la expulsión de hogares de menores ingresos. Siendo una de las caras más visibles de la reconfiguración de las relaciones de clase en las ciudades, el desplazamiento ocurre por una serie de mecanismos y formas coercitivas de violencia, sea ésta material, política, simbólica o psicológica. De manera abstracta, puede definirse como una operación que restringe las opciones de los sectores de menores ingresos de encontrar un lugar adecuado para vivir en un espacio concreto, sobre todo cuando otros grupos sociales con mayor capital económico, social y cultural llegan a vivir a este espacio ${ }^{7}$. En este sentido, indica lo que ocurre cuando fuerzas externas al entorno del hogar imposibilitan mantener o desarrollar la vida en un lugar, por diferentes razones ${ }^{8}$. Pero, ¿cuáles son estas fuerzas, cómo actúan, y cómo es posible conceptualizarlas para poder ilustrar mejor el vínculo entre desplazamiento, desposesión y gentrificación?

Para acercarnos a esta cuestión, parece adecuado comenzar con la distinción de dos acepciones: por un lado, hacer constar la argumentación

$7 \quad$ Slater, 2009.

8 Hartmann, Keating y LeGates, 1982. about the displacement and dispossession that gentrification implies for the popular classes.

Gentrification is a process resulting from specific economic and political assemblages that provoke accumulation by dispossession and operates through the displacement and eviction of lowerincome families. Regarded as an example of the reconfiguration of class relationship within cities, the displacement occurs by a series of mechanisms and coercive forms of material, political, symbolic or psychological violence. In abstract terms, displacement can be defined as an operation that prevents lower-income groups from finding an adequate place to live, especially when there are groups with higher economic, social and cultural status who are seeking to inhabit in the same space. This phenomenon explains what happens when external forces, for a variety of reasons ${ }^{8}$, prevent certain groups from living in a given place. However, what are these forces? How do they operate? How can they be conceptualized in order to explain the relationship between displacement, dispossession and gentrification?

To address these questions, it is worth making a distinction between two notions. On the

7 Slater, 2009

8 Hartmann, Keating and LeGates, 1982. 
desarrollada por Peter Marcuse $^{9}$ a partir de un análisis estadístico del mercado inmobiliario en Nueva York hace ya más de tres décadas. En ese trabajo distinguió cuatro categorías analíticas que expliquen los mecanismos de desplazamiento y que son: (i) desplazamiento directo del último residente, (ii) desplazamiento en cadena, (iii) desplazamiento por exclusión (iv) presión de desplazamiento. Si bien estas categorías podrían servir como aproximación inicial para reflexionar acerca del desplazamiento de las clases populares en las ciudades latinoamericanas, cabría introducir cierto cuidado: se podría pecar de la importación acrítica de una conceptualización que carece de relación con las realidades en las ciudades de la región, además de relegar los cambios que ocurrieron en las políticas urbanas desde el inicio del experimento neoliberal a un segundo plano. Como admite Marcuse ${ }^{10}$, éstos eran difíciles de anticipar a principios de la década de 1980. Además, a la luz de las especificidades de los procesos de gentrificación en América Latina, resultaría incauto pensar el desplazamiento únicamente mediante el análisis estadístico de las modificaciones residenciales.

Por otro lado, cabría resaltar que el desplazamiento debería ser abordado mediante una reflexión acerca de las relaciones de poder existentes que definen y estructuran los discursos oficiales, por tanto pensar

9 Marcuse, 1985.

10 Marcuse, 2015 one hand, there is the proposal developed by Peter Marcuse $e^{9}$, which is based on a statistical analysis of the situation of the real estate market in New York three decades ago. This work defined four analytical categories that explained different displacement mechanisms: (i) direct last-resident displacement; (ii) chain displacement; (iii) exclusionary displacement; and (iv) displacement pressure. While these categories help us to reflect on the displacement of popular classes in Latin American cities, careful attention should be given to some specific aspects: what is being imported is a concept that has only little relationship with local realities and overshadows the changes undergone by public policies since the beginning of the neoliberal experiment. As Marcuse $e^{10}$ pointed out, these changes were difficult to predict back in the early 1980s. Likewise, given the specific nature of gentrification processes in Latin America, it would be incautious to think about displacement by focusing exclusively on the statistical analysis of residential change.

On the other hand, the displacement phenomenon should be addressed in terms of the power relations that define and articulate official

$9 \quad$ Marcuse, 1985. 
el papel de las políticas públicas ${ }^{11}$. En línea con esto, García-Herrera et al. ${ }^{12}$ indican que "ya que el Estado a diferentes niveles adopta la gentrificación como una política de vivienda (...) tiene poco interés propio en recopilar la clase de datos que documente el grado de desplazamiento"; sobre todo porque tales datos probarían el fracaso de los discursos políticos habituales. Esto implica tener en consideración las limitaciones metodológicas que los debates sobre desplazamiento muestran habitualmente ${ }^{13}$. Por ejemplo, buena parte de los datos cuantitativos son rudimentarios y no permiten el análisis pormenorizado de barrios concretos o comparaciones en el tiempo. Una reflexión crítica podría considerar esa ausencia de datos como un tipo específico de poder administrativo que es estratégico para las políticas urbanas: se trataría de una "técnica de gubernamentalidad"14 específica que se aplica mediante la omisión y transforma el interés por el desplazamiento en una cuestión política.

A partir de los dos argumentos se desprende que el desplazamiento no es simplemente la salida involuntaria de población que puede ser contabilizada por métodos estadísticos (desplazamiento directo). Expresa una problemática mayor, la injusticia social y espacial que lastra a ciertos grupos en su derecho legítimo a la ciudad, y especialmente en

11 Lees, 2012.

12 García, Smith y Mejías, 2007, p. 280.

13 Slater, 2009

14 Sequera y Janoschka, 2015. discourses; this leads us to think of the role of public policies ${ }^{11}$. According to García-Herrera et. al." "as the state at various scales adopts gentrification as a housing policy [...] it has little self-interest in collecting the kind of data that documents the level of displacement", especially because this information may reveal the failure of political discourses. This implies that attention should be given to the methodological limitations of the debates on displacement ${ }^{13}$. For instance, most of quantitative data is rudimentary in nature and does not allow analysis of concrete neighborhoods or comparisons across time. Some critical reflections may associate this lack of information with a specific type of administrative power that seems to be strategic within the context of urban policies: this may be a specific "governmental technique" 14 that is based on omission and transforms the concerns about displacement into a political question.

These two arguments indicate that displacement does not only refer to the involuntary movement of people -which is recorded through statistical methods (direct displacement). It also refers to the social and spatial injustice that impinges

\footnotetext{
Lees, 2012.

García, Smith and Mejías, 2007, p. 280.

Slater, 2009.

Sequera and Janoschka, 2015.
} 
su derecho a usufructo de la centralidad. En este sentido, el desplazamiento no es solamente un elemento intrínseco de la producción urbana capitalista. También alberga una perspectiva que es simultáneamente analítica y política ${ }^{15}$. Este último aspecto se aprecia en los discursos de la academia latinoamericana. Una "etimología" del uso del término en América Latina ${ }^{16}$ destacaría tres diferentes nociones:

(i) Desplazamiento como un cambio de lugar que ocurre por mayor o menor fuerza externa, debido a procesos tan variados como la migración, los desastres naturales, los conflictos políticos o militares, o en relación a proyectos de infraestructura y acondicionamiento del territorio;

(ii) Desplazamiento como movilidad territorial que se relaciona fundamentalmente con el transporte y la movilidad urbana regular (diaria);

(iii) Desplazamiento como proceso de desposesión, sea por el abandono de viviendas, la erradicación de asentamientos informales, una expulsión "negociada" o una remoción con fines pedagógicos, civilizatorios o morales.

\footnotetext{
15 Slater, 2009.

16 La revisión bibliográfica en la cual se basa la tipificación fue efectuada por Blanco y Apaolaza, 2016.
}

the legitimate right of people to the city; especially when it comes to their right to the enjoyment of the benefits of centrality. In this sense displacement is not only inherent to urban capitalist production but also reflects an analytical and political perspective ${ }^{15}$. The latter can be observed in the discourses of the Latin American academy. In etymological terms, and within the Latin American context ${ }^{16}$, the term displacement may be referred to as:

(i) a change of place that occurs as the result of greater or lesser external forces such as migration, natural disasters, political or military conflicts, infrastructure and territorial development projects;

(ii) a type of territorial mobility that is mainly associated with transport and daily urban mobility;

(iii) a dispossession process that is caused by abandonment, eradication of informal settlements, "negotiated" eviction or expulsion due to teaching, civilizing or moral purposes.
15 Slater, 2009.

16 This classification is based on a literature review conducted by Blanco and Apaolaza, 2016. 
El marco analítico para la comprensión del desplazamiento se relacionaría principalmente con esa tercera acepción, en un intento de entender la recomposición del espacio urbano como "acumulación por desposesión". Cuando David Harvey ${ }^{17}$ desarrolló esa noción para actualizar el concepto marxista de "acumulación originaria", subrayó que se trata de un proceso extractivo permanente. Si la acumulación originaria significaba la reorganización de la sociedad capitalista a través de los derechos de la propiedad privada y la mercantilización de los bienes comunes, los recursos naturales y la fuerza del trabajo, la "acumulación por desposesión" tendría que ver con la nueva oleada de acotamiento de los bienes comunes, especialmente los que fueron desarrollados y creados por las clases populares en pos de limitar los intentos empresariales de valorar el espacio urbano ${ }^{18}$. Siguiendo a Sassen ${ }^{19}$, en el escenario actual la acumulación por desposesión se formaliza mediante la expulsión territorial de los que el mercado no necesita, al mismo tiempo que éste intenta incorporar a los circuitos de la acumulación capitalista los valores simbólicos y los recursos materiales de cualquier espacio considerado como "deseado". A diferencia de la acumulación originaria cuya intención consistió en incorporar los desposeídos a las relaciones capitalistas del mercado laboral, la

17 Harvey, 2004.

18 Gillespie, 2016

19 Sassen, 2014.
The analytical framework designed for the study of displacement is mainly associated with the third argument as it seeks to understand the reconfiguration of urban space as "a process of accumulation by dispossession". This concept, developed by David Harvey ${ }^{17}$ to update the Marxist theory of primitive accumulation, can be considered as a permanent extractive process. If primitive accumulation referred to the reorganization of the capitalist society through the right to private property and the commodification of common goods, natural resources and the workforce, "accumulation by dispossession" is associated with the commodification of the commons-especially those developed and created by popular classes to limit the entrepreneurial attempts to valorize urban space ${ }^{18}$. According to Sassen ${ }^{19}$, accumulation by dispossession operates through the expulsion of those who are not required by the market, at the same time as it seeks including the symbolic values and material resources of every space considered as "desired" to the circuits of capital accumulation. Unlike primitive accumulation -which was intended to incorporate the dispossessed into the capitalist relationships of the labor market- the current

\footnotetext{
17 Harvey, 2004.

18 Gillespie, 2016.

19 Sassen, 2014.
} 
finalidad ahora consiste principalmente en expulsarles de los lugares céntricos de la ciudad, en los cuales están demasiados visibles para que "funcionen" las estrategias de revalorización. Para mayor claridad, cabe señalar que la limpieza social y la "modernización selectiva"20 de las ciudades latinoamericanas se fundamentan en mecanismos de acumulación por desposesión del hábitat. Se trata de un fenómeno en directa relación con cinco dimensiones fundamentales de reproducción social: la vivienda, el suelo, los bienes comunes (entre los cuales destaca el espacio público), la movilidad, y la propia constitución y autonomía del sujeto. Esta perspectiva permite introducir un análisis mucho más nítido de las políticas públicas, ya que reduce la exposición excesiva que Harvey le atribuye a los procesos de reproducción del capital. En este sentido, cabe resaltar que si bien el Estado no es un agente monolítico, suele facilitar mediante su acción u omisión las dinámicas urbanas que fomentan los procesos de acumulación y reproducción del capital, en lugar de proteger los intereses legítimos de las clases populares, y esto debería reflejarse en el análisis del desplazamiento. Además, introducir la noción del hábitat en las dinámicas de acumulación y desposesión nos permitirá extender el análisis a la (re-) apropiación espacial por parte de las clases populares y la consiguiente construcción de "territorios en resistencia"21.

20 Delgadillo, 2016.

21 Zibechi, 2008. goal is to expulse deprived individuals from the central areas of the city as their presence may endanger the proper "functioning" of revaluation strategies. For clarity, it is worth mentioning that social cleansing and the "selective modernization"20 of Latin American cities are based on mechanisms associated with a phenomenon regarded as "accumulation by habitat dispossession". This phenomenon is directly related to the five essential dimensions of social reproduction: housing, land, common (such as public space), mobility and the constitution and autonomy of subjects. This perspective allows us to conduct a more detailed analysis of public policies since there is a reduction of Harvey's excessive focus on capital reproduction. In this sense, it is worth noting that while the State is not a monolithic agent, its actions or omissions contribute to the promotion of capital accumulation and reproduction processes, thus ignoring the legitimate interests of lower-income groups -such a situation should be reflected in the displacement. Likewise, the incorporation of the concept of 'habitat' into the accumulation and dispossession dynamics allows us to further explore the spatial (re)

Delgadillo, 2016. 
A continuación, se precisa una propuesta para acotar el desplazamiento como proceso complejo, sin perder de vista su aplicabilidad para el análisis empírico. Por ende, se propone diferenciar las siguientes cuatro dimensiones que idealmente compondrían las lógicas del desplazamiento:

Desplazamiento como proceso material, de índole económico-financiera: el desplazamiento como proceso material es el que mayor visibilidad y repercusión tiene, ya que se trata de la expulsión directa de los hogares de un lugar concreto. Si bien implica un amplio abanico de lógicas, como lo pueden ser los mercados de (micro) créditos, la financiarización de la vivienda o los mecanismos de "redlining"22, consiste principalmente en la aplicación de la racionalidad económica tradicional del mercado inmobiliario a la vivienda, que son la inversión, la compra y la venta, y el alquiler. Estas lógicas tienen una alta capacidad de segregar, separar y expulsar. El consiguiente desplazamiento material se visibiliza en las (escasas) estadísticas y concentra la mayor parte de la atención mediática y científica al fenómeno.

Desplazamiento como proceso político: si bien el desplazamiento como proceso material parece ser el más visible, es impensable sin el proceso

22 Este término denomina los mecanismos estadísticos geo-referenciados que influyen en la concesión de créditos, independientemente de la capacidad crediticia del hogar. Para mayor detalle, véase Aalbers, 2013. appropriation led by low-income people and the subsequent construction of "territories in resistance" 21 .

The following is a proposal intended to understand displacement as a complex process -attention is also given to its applicability for empirical purposes- and identify four dimensions that may compose this phenomenon:

\section{Displacement as an economic-financial} material process: This the most visible kind of displacement as it involves direct expulsion. While determined by a series of factors such as (micro) credits, the financialization of housing or redlining ${ }^{22}$, this process is based on the application of the traditional economic rationale of real estate markets -investment, purchasing, selling and renting. These are highly segregating, dividing and expulsing factors. The subsequent material displacement can be observed in the (few) statistics available; this kind of displacement also receives the most media and research attention.

\footnotetext{
21 Zibechi, 2008.

22 This term refers to the statistical geo-referenced mechanisms that influence the granting of loans, regardless of the creditworthiness of borrowing households. For further details see Aalbers, 2013.
} 
político que lo constituye. El desplazamiento como proceso político implica dotarle a los procesos de reconfiguración urbana que operan en el plano material, económico y financiero de autoridad legal y procedimiento político-administrativo, además de protección jurídica y acceso a las fuerzas del orden público para su implementación. En este sentido, el desplazamiento como proceso político puede considerarse como tarea fundamental que ejerce el Estado como actor que regula, supervisa y ordena el desarrollo territorial. Implica una amplia gama de actuaciones, desde la configuración de políticas públicas específicas, la licitación de los Grandes Proyectos Urbanos, la elaboración de los Planes Generales o Parciales para la planificación funcional del espacio urbano hasta la aplicación, más reciente, de políticas de control, vigilancia, securitización y comercialización del espacio público. Incluso, puede incluir la tolerancia de infracciones legales, micro-políticas de corrupción y nepotismo, y otras tantas relaciones no previstas en ninguna legislación.

Desplazamiento como proceso simbólico: el hecho que el desplazamiento material fuese tan exitoso a lo largo de la historia de las ciudades no solamente se asocia con las relaciones de poder que se escenifican entre los diferentes actores económicos y políticos, sea en asuntos públicos o en la esfera privada. Más bien, corresponde también con los aspectos simbólicos que se constituyen en el interior de las sociedades. La gran mayoría de estos procesos
Displacement as a political process: Despite its visibility, material displacement would not occur without a political process. This second type of displacement implies providing material, economic and financial urban reconfiguration processes with legal authority, politicaladministrative procedures, judicial protection and the cooperation of law enforcement agencies to operate properly. In this sense, this process may be regarded as an essential State-led activity since this actor regulates, supervises and steers territorial development. There is also a wide array of interventions, such as the elaboration of specific public policies, tendering procedures for Major Urban Projects, redevelopment programmes, the implementation of planning legislations, policies focused on control, surveillance and securitization, as well as the commodification of public space. However, this includes simultaneously a tolerance for legal violations related to corruption, nepotism and other relations not foreseen in planning laws.

Displacement as a symbolic process: The success of material displacement throughout the history of cities is not only associated with power relations between economic and political actors-either within public or private spheres-, but also with the symbolic aspects that rule the constitution of societies. These processes may 
recuerdan a la constitución de un iceberg, ya que apenas una mínima fracción aparece en el campo de lo visible, mientras que gran parte queda sumergida en el reparto pre-discursivo de lo sensible o en estructuras y configuraciones discursivas y simbólicas que resultan difícilmente observables. Sin embargo, constituyen la base para la reconfiguración de las ciudades y permiten una aproximación a la formación y recreación de la sociedad como proceso holístico, como micro-políticas que se aplican constantemente, consciente e inconscientemente desde las múltiples posiciones subjetivas que cada uno de los actores ocupa. Parte de la constitución del campo simbólico se relaciona con las grandes instituciones sociales y políticas, el Estado o los medios de comunicación. Otra parte está imbricada en la vida diaria de todos, como emprendedores, profesionales, consumidores, vecinos y habitantes de un barrio. Los procesos simbólicos guardan mucha relación con las prácticas de poder subyacentes denominadas por algunos autores como "colonialidad del saber" ${ }^{23}$. Esta logra mantener unas prácticas como 'invisibles', define otras como "criminales" y canaliza tanto el repudio como la admiración social hacia otras. Como consecuencia ocurre que las subjetividades asociadas a las clases populares experimentan una estigmatización discursiva que determina la construcción simbólica de la sociedad, traduciéndose en un es-

23 Santos, 2010. resemble the composition of an iceberg as what can be observed is just a small fraction “... of the reality which, although mainly invisible, is composed of a pre-discursive distribution of symbolic structures and configurations. This distribution is essential for the reconfiguration of cities, as it comprises an understanding of the formation and recreation of the society as a holistic process. In this regard, there are micro-politics that are constantly applied, both conscious and unconsciously from different subjective positions that each of the actors occupies. Some parts of the constitution of the symbolic field is related to the major social and political institutions, the State and the media. The rest of this dimension is embedded in the daily lives of people, whether they are entrepreneurs, professionals, consumers, neighbors or inhabitants of a neighborhood. Symbolic processes are closely related to underlying practices of power, which have been denominated by some authors as "coloniality of knowledge"23. This concept addresses that certain practices remain 'invisible' within our society, while others get defined as 'criminal'. At the same time, it canalizes the social admiration towards other practices. As a result, lower-class subjectivities are discursively stigmatized, thus

23 Santos, 2010. 
pacio urbano homogéneo que corresponde con el gusto de las clases medias, los sujetos definitorios de la espacialidad contemporánea. En otras palabras, la constitución simbólica de la sociedad implica que los procesos de desposesión están relacionados con las disputas por la hegemonía cultural $^{24}$, disputas que afectan todas las dimensiones de la vida diaria.

Desplazamiento como proceso psicológico: cabe destacar que el desplazamiento como proceso simbólico, por la profundidad y oscuridad en la cual opera, puede considerarse como aspecto elemental que necesitaría desenmascararse empíricamente para comprender el éxito del desplazamiento como proceso material y político, una tarea todavía incipiente en los estudios urbanos. Además, esta operación ganaría posición si se relacionara con profundizar el desplazamiento como proceso psicológico. Se trata de una dimensión ubicada a nivel individual que problematiza los efectos que el desplazamiento tiene en la constitución psicológica de las personas. Se relaciona íntimamente con las múltiples violencias simbólicas que afectan la vida diaria. Implica la dislocación y el aislamiento social que tienen lugar en un barrio desde antes del desplazamiento material, y que se producen a causa de los cambios materiales, políticos y sociales inducidos, independientemente del

24 Paton, 2014. determining the symbolic construction of society and leading to the emergence of a homogeneous urban space that is tailored to the preferences of middle-class individuals -who have the final say on the definition of contemporary spatiality. In other words, the symbolic constitution of society implies that dispossession is related to the dispute over cultural hegemony ${ }^{24}$, affecting all aspects of daily life.

\section{Displacement as a psychological process:} Given the psychological deepness and obscurity in which symbolic displacement operates, it is essential to further address it for empirical exploration. This would help to better address the successful mechanisms that guide displacement as a material and political process. However, such task has only just begun to be developed. Additionally, the process of deciphering the symbolic constitution of society may become increasingly important if it related to the psychological process that displacement implies. Displacement as a psychological process refers to an individual perspective that problematizes the effects that it has on the psychological constitution of individuals. It is closely related to different types of symbolic violence that affect daily life. Considering displacement as
24 Paton, 2014. 
desplazamiento material ${ }^{25}$. Estos cambios provocan sentimientos de "perdida de lugar"26, múltiples procesos de alienación, estrés en la vida diaria y severas consecuencias en términos psicológicos. A partir de nuevos marcadores simbólicos se perpetúa la violencia simbólica asociada a la construcción de hegemonía discursiva por la población de mayores ingresos. Toda transformación del barrio que demuestra la imposibilidad de influenciarla por activa o pasiva estimula sentimientos negativos, resentimientos, enojo y sensaciones de injusticia, provocando daños en los lazos afectivos que conforman el "capital espacial"27 de un individuo o núcleo de hogar en un espacio concreto. Dicho de otro modo, el cambio material, estético o comercial de un barrio motivado por la inversión de capital implica un desplazamiento en términos psicológicos, incluso si el hogar se mantiene físicamente en el lugar.

Como es posible observar a partir de esta caracterización, el desplazamiento es multifacético. Si bien se entiende que en la realidad las nociones presentadas están íntimamente relacionadas y apenas separables, el ejercicio de disgregación teórica consiste en un intento de simulacro dialéctico que permita desarrollar una comprensión y articulación analítica de mayor profundidad. Por tanto,

25 Atkinson, 2015.

26 Shaw y Hagemans, 2015; Hodkinson y Essen, 2015.

27 Apaolaza, Blanco, Lerena, López, Lukas y Rivera, 2016. a psychological process means also addressing the dislocation and social isolation that take place in a neighborhood because of material, social and political changes, prior to and independently from the material displacement ${ }^{25}$. Such changes provoke a sense of 'loss of place'26 and generate multiple alienation amongst inhabitants, stress and serious psychological consequences. The presence of new symbolic markers perpetuate symbolic violence, which is associated to the construction of discursive hegemony by higher-income groups. Each type of neighborhood transformation that cannot be influenced by active or passive methods generates negative feelings, resentment, anger and a sense of injustice, thus damaging the emotional bonds that make up the "spatial capital" 27 of individuals or households within a given space. In other words, capital investments and the subsequent material, aesthetic or commercial transformation of neighborhoods generate psychological displacement, even if the households physically stay put.

This categorization allows us to observe the multiple characteristics of displacement. While it is well understood that these notions are

\footnotetext{
25 Atkinson, 2015.

26 Shaw and Hagemans, 2015; Hodkinson and Essen, 2015.

27 Apaolaza, Blanco, Lerena, López, Lukas y Rivera, 2016.
} 
se considera preciso desenmascarar especialmente los aspectos que a primera vista parecen recónditos. Éstos se sitúan principalmente en el campo de los procesos políticos, simbólicos y psicológicos, y ocultan violencias de diferente índole pero con enorme importancia para una comprensión más completa del desplazamiento de las clases populares de las áreas centrales y peri-centrales que está teniendo lugar en muchas de las grandes ciudades latinoamericanas.

\section{Desplazamiento y desposesión en cinco ciudades latinoamericanas; una tipificación}

A continuación, se pretende ahondar en los procesos de acumulación por desposesión del hábitat cuyos mecanismos que se han caracterizado anteriormente de forma teórica, aplicando la sistematización de desplazamiento a cinco ciudades latinoamericanas: Ciudad de México, Buenos Aires, Río de Janeiro, Santiago de Chile y Quito. El trabajo analítico consiste en descifrar las lógicas detrás de cinco tipos de desposesión que ocasionan desplazamiento en estas ciudades. El consiguiente proceso de destacar, perfilar y tipificar, implica un ejercicio didáctico que reduce complejidad para lograr mejor entender el desplazamiento como practically indissoluble and closely related to each other, this theoretical disaggregation exercise aims at providing providing through a dialectic simulation a much deeper analytical comprehension. Therefore, there is a need to reveal those apparently hidden aspects. They are usually found in political, symbolic and psychological processes and disguise different types of violence of crucial importance for the understanding of the displacement of popular classes from the central and peri-central areas of Latin American cities.

\section{Displacement and Dispossession in Five Latin American Cities; a Tipification}

This section aims at exploring empirically the processes of accumulation by habitat dispossession, which have been discussed theoretically thus far. This will take place by applying the previous systematization of displacement in five Latin American cities: Mexico City, Buenos Aires, Rio de Janeiro, Santiago de Chile and Quito. This analytical procedure consists in understanding the logics of five types of displacement that generate dispossession. The following process -which highlights, outlines 
proceso material, político, simbólico y psicológico. No obstante, la sección comenzará por una breve introducción a los lugares concretos a partir de los cuales se ha desarrollado el análisis empírico.

\section{LOS LUGARES DEL DESPLAZAMIENTO | CIUDAD DE MÉXICO, BUENOS AIRES, RIO DE JANEIRO, SANTIAGO DE CHILE Y QUITO}

Los lugares del desplazamiento en los cuales se inspira la siguiente tipificación abarcan una gran variedad en tamaño, ubicación, densidad habitacional y complejidad social. Por ende, su denominador común consiste en haber experimentado, a lo largo de los últimos quince años, amplias reconfiguraciones territoriales que implicaron algún tipo de desplazamiento de subjetividades asociadas a las clases populares. En la Ciudad de México, se trata del "rescate" del centro histórico, el patrimonio histórico quizás de mayor importancia en América Latina, así como del mercado de la Merced, que se ubica en la inmediatez geográfica del centro histórico y que constituye el mercado municipal de mayor extensión en América Latina. El estudio de Buenos Aires se concentra en tres áreas diferentes que se unen discursivamente por una sola lógica: la valorización del espacio urbano a partir del recurso al patrimonio cultural del Tango. En detalle, se trata de las zonas que rodean al antiguo mercado central (Abasto), así como algunas partes de los barrios de San Telmo y La Boca and classifies specific elements- involves a didactic exercise that reduces complexities in order to better understand displacement as a material, political, symbolic and psychological process. However, this section begins with a brief introduction to the spaces on which this empirical analysis is based.

\section{THE SITES OF DISPLACEMENT | MEXICO CITY, BUENOS AIRES, RIO DE JANEIRO, SANTIAGO, QUITO}

The sites of displacement that inspire the subsequent tipification differ in size, location, housing density and social complexity. However, they have experienced widespread territorial reconfigurations, as well as and the resulting displacement of subjectivities associated to popular classes over the last 15 years. In the case of Mexico City, attention is given to the "rescue" of the historic city center-perhaps the most important heritage site in Latin America- and its neighboring market "La Merced", one of the largest markets in Latin America. The analysis of Buenos Aires is focused on three different areas that converge on the valorization of urban space related to the cultural heritage embodied by Tango. These areas are located near the former central market (Abasto) and some areas of San Telmo and La Boca, located in the southern parts 
en el sur de la Ciudad Autónoma. En el caso de Río de Janeiro, el trabajo de investigación se concentró fundamentalmente en Vila Autódromo, una comunidad de autoconstrucción que se ubica próximo al parque olímpico. Si bien esta localización es de carácter peri-central, se encuentra plenamente integrado en el eje de expansión inmobiliaria actual que se dirige a las capas medio-altas y altas de la ciudad y puede informarnos acerca de las lógicas que están detrás de la transformación de la ciudad asociada a los grandes eventos deportivos. En la región metropolitana de Santiago de Chile se parte del análisis genérico de la reconfiguración espacial de las comunas centrales y peri-centrales, tras haberse efectuado un trabajo pormenorizado en la comuna de Peñalolén. Finalmente, el caso de Quito se abstrae del trabajo de investigación desarrollado en dos parroquias rurales de la periferia de la ciudad en plena transformación por avance de los procesos de suburbanización: Cumbayá y Calderón. La primera de ellas se caracteriza por haberse transformado en un enclave de desarrollo habitacional para sectores de alta renta, y la segunda es una periferia popular, de origen informal que ha sido objeto de interés de nuevos desarrollos tanto del sector público como privado. of the city. As for Rio de Janeiro, this research analyzed the case of Vila Autódromo -which is a self-constructed community located near the Olympic park. This space can be found in a periurban area that is currently being re-developed to attract upper-middle and upper classes; this example provides clues on the logics that operate when the city is transformed as the result of the organization of major sports events. In the case of the metropolitan region of Santiago, Chile, a generic analysis of the spatial reconfiguration processes in central and peri-central areas is offered, with a focus on the situation of the Municipality of Peñalolén. Finally, the case of Quito is focused on Cumbayá and Calderón, two rural counties located in the outskirts of the city that are being transformed as the result of suburbanization. While the first place is characterized for becoming a real estate enclave for higher-income groups; the second area is a popular and informally constructed space that has been drawing the attention of both public and private actors. 


\section{DESPLAZAMIENTO POR DESPOSESIÓN DEL PATRIMONIO ARQUITECTÓNICO | CIUDAD DE MÉXICO}

En la Ciudad de México se observa un desplazamiento cuyo dispositivo se define como desposesión del patrimonio arquitectónico. Se origina principalmente con la finalidad de poner en valor el patrimonio del centro histórico que consiste de más de 9.000 edificios, 1.500 de ellos listados como patrimonio histórico o artístico ${ }^{28}$. Implica el intento de desplazar los hogares de bajos ingresos que vivían $y$, como se trata de un proceso inacabado, siguen coexistiendo en el área. Como proceso material, se relaciona con el interés del inversor Carlos Slim en el barrio, ya que compró varias docenas de edificios de importancia histórica y simbólica. Tras su renovación, muchos de los edificios padecieron una modificación de su uso, para albergar instituciones educativas o culturales, o convertirse en museos, hoteles, cafés y restaurantes, o a pasar por alquilarse a estudiantes, artistas, o incluso políticos, desplazando a sus ocupantes previos ${ }^{29}$. El segundo efecto ha sido el desplazamiento de usuarios del espacio público, especialmente los vendedores ambulantes, cuyo número fue estimado en más de 30.000 a comienzos de siglo ${ }^{30}$. Recientemente, se ha extendido al colindante barrio de la Merced y

28 Delgadillo, 2008.

29 Betancur, 2014.

30 Crossa, 2009.

\section{DISPLACEMENT BY DISPOSSESSION OF ARCHITECTURAL HERITAGE | MEXICO CITY}

In Mexico City, displacement can be defined as the "dispossession of architectural heritage". Its key element consists of the valorization of the heritage of the historic city center, which consists of more than 9,000 buildings -1,500 of them listed as historic or artistic heritage ${ }^{28}$. This implies the intent of displacing low-income households from the area. However, as it is an ongoing process, popular classes still coexist in the area. From a material perspective, this process is associated with the plans of Mexican investor Carlos Slim, who purchased and remodeled a series of hhistorically and symbolically important buildings to serve as educational and cultural institutions, museums, hotels, cafes, restaurants or provide accommodation to students, artists or even politicians, thus displacing previous dwellers ${ }^{29}$. The second consequence has been the displacement of users from public space; particularly important is the case of street vendors, whose number was estimated at 30,000 at the beginning of the century. ${ }^{30}$ This phenomenon is currently being reproduced in the neighboring district of La Merced and

\footnotetext{
28 Delgadillo, 2008.

29 Betancur, 2014.

30 Crossa, 2009.
} 
a su mercado, en el que tuvo lugar la expulsión material de una parte de los comerciantes informales que ocuparon el espacio público contiguo, así como intentos de desalojo de comerciante en diferentes naves del mercado.

Este desplazamiento material tiene una íntima relación con la aplicación de políticas públicas que aspiran a transformar en primer lugar el espacio público, mediante políticas de securitización, higienización y expulsión de los usos que no parecen "adecuados" para garantizar rentabilidad de las inversiones. Por tanto, el centro histórico se dotó de un plan estratégico en temas de seguridad que fue redactado por la empresa de consultoría del ex alcalde de Nueva York, Rudolph Giuliani. La implementación del plan implica un control férreo del espacio público, mediante (video) vigilancia y presencia policial permanente. En segundo lugar, se han aplicado políticas públicas para impedir la apropiación comercial del espacio por parte de vendedores ambulantes. Primero el comercio ambulante ha sido declarado ilegal, para luego expulsarlo materialmente en una acción policial de tinte militar, efectuada en octubre de $2007^{31}$. En tercer lugar, cabe señalar el rol destacado que adquirió el Fideicomiso del Centro Histórico, organismo que apoyó la reordenación del tráfico vehicular, la inversión en el espacio público así como el plan de rehabilitación de edificios. Y finalmente, en la fase

31 Becker y Müller, 2013; Davis, 2013. its market. In this case, informal vendors who operated in adjacent public space have been materially evicted and there have also been attempts to evacuate traders from different areas of the market.

Such a material displacement is closely related to the implementation of policies intended to transform public spaces through security and sanitation measures and the eviction of uses that may hinder the capital return of investment. In this context, the consulting firm owned by former NYMayor Rudolph Giuliani was commissioned to develop a strategic security plan for the historical center. This initiative involves tight control of public space through (video) surveillance and permanent police presence. Likewise, a series of public policies have been implemented to prevent street vendors from operating in these spaces. This activity was first declared as illegal and then materially evicted through a military-like police operation in October, 200731. It is worth mentioning the role played by the "Historical City Center Trust", which contributed to the reorganization of vehicular traffic, investment in public spaces and the refurbishment of buildings. Then there is the recent situation of the ' $\mathrm{La}$ Merced' market, which, after decades of neglect

31 Becker and Müller, 2013; Davis, 2013. 
más reciente destaca la gestión del mercado de la Merced, que está pasando por un proceso opaco de renovación, rehabilitación e inversión pública, tras varias décadas de abandono y desinversión.

Si bien el proceso de desplazamiento material se ha visto obstaculizado y contestado por la realidad específica de la organización vecinal y la forma de ocupación histórica que tiene del lugar, el dispositivo de acumulación por desposesión del patrimonio arquitectónico ha provocado importantes disputas y se traduce en territorios dispares. Si se plantea el desplazamiento como proceso simbólico, cabe señalar la necesidad del capital de emplear formas sutiles e indirectas para expulsar las identidades populares del centro histórico. Este es especialmente el caso cuando existen intereses potenciales para el turismo y el ocio de población no residente, ya que éstos implican formas opuestas de apropiación del espacio. Por ende, es posible distinguir tres diferentes tipos de violencia simbólica: (i) la violencia de la hiper-seguridad que es requerida para controlar el espacio público; (ii) la violencia étnica y racial que es impuesta por la "superioridad" estética del gusto de las clases medias y altas; (iii) la violencia turística, que es una fuerza intangible con alto potencial de desposesión en términos simbólicos y materiales, implicando además efectos psicológicos por la usurpación del espacio para visitantes, en detrimento de la población residente. and disinvestment is currently undergoing an opaque process of renovation, rehabilitation and investment.

While the material displacement process has been hindered and challenged by the specific reality of neighborhood organization and the historic occupation of space, the dispositive of accumulation by dispossession of architectural heritage has generated some important disputes and uneven spaces. When understood as a symbolic process, displacement implies the necessity of capital to apply subtle and indirect eviction of popular subjectivities from the historic center. This is especially true when there is a potential for the development of tourism and recreational activities for non-resident individuals since they implicate diametrically opposite ways to appropriate space. Therefore, it is possible to identify three types of symbolic violence: (i) violence of hyper-security, which is associated with the control of public spaces; (ii) ethnic and racial violence, which is imposed by the esthetically "superior" preferences of middle and upper classes; and (iii) violence of tourism, which is a highly dispossessing and intangible force -in symbolic and material terms- that has psychological effects as the result of the 


\section{DESPLAZAMIENTO POR DESPOSESIÓN DEL PATRIMONIO CULTURAL | BUENOS AIRES}

En Buenos Aires, el desplazamiento observado se caracteriza como desposesión del patrimonio cultural. A diferencia con el caso anterior, se trata de un tipo de patrimonio inmaterial que es origen y destino del proceso material: el Tango, desde 2009 inscrito en la lista de la UNESCO. Si bien según el lugar concreto este se efectúa en diferentes momentos, tiene en común el desplazamiento de habitantes vulnerables en los correspondientes barrios (como ocupantes de edificios abandonados o sectores de rentas bajas). Cabe señalar que el área del Abasto tuvo su impulso ya en la década de 1990, cuando se remodeló el edificio del mercado, transformándolo al mayor centro comercial de la ciudad. Además, fueron construidos un hotel, un hipermercado y varias torres con aproximadamente 1.100 apartamentos. En paralelo, muchos de los arrendatarios de propiedades vecinas fueron desplazados hacia lugares periféricos ${ }^{32}$. En San Telmo, el proceso es posterior y comprende una reorientación comercial, principalmente a través de establecerse el barrio como sede de instituciones culturales, teatros, librerías, restaurantes y cafés-concierto, muchos de ellos vinculados al Tango. Además, también el mercado inmobiliario se transformó. San Telmo se ha convertido en un lugar idóneo para alquileres usurpation of space for tourist purposes at the expense of local residents.

\section{DISPLACEMENT BY DISPOSSESSION OF CULTURAL HERITAGE | BUENOS AIRES}

In Buenos Aires, the observed displacement may be characterized as the dispossession of cultural heritage. Unlike the previous case, this refers to an immaterial heritage, which is the origin of the material process of displacement: Tango, which was inscribed to the list of intangible heritage of the UNESCO in 2009. Although the related dispossession occurs in different spaces and in different moments of the recent urban history, it has in common the expulsion of the most vulnerable dwellers, for instance occupiers of previously abandoned buildings. It is worth noting that the Abasto area was already being promoted back in the 1990s; such an initiative included the renovation of the market, thus becoming the largest shopping center in the city. Additionally, investment in the construction of a hotel, a huge supermarket and apartment blocks with approximately 1,100 flats took place. In parallel to this, tenants of adjacent properties were displaced to peripheral urban

32 Carman, 2011; Centner, 2012. 
de corto y mediano plazo que en muchos casos están relacionados con el turismo. Finalmente, en La Boca se originaron varios proyectos inmobiliarios de viviendas tipo loft que aspiran atraer talleres artísticos. Además, se ha informado también de cierta violencia material que consiste de desahucios forzosos, incendios de edificios (por razones "oficialmente" desconocidas y no investigadas) y otras reubicaciones involuntarias ${ }^{33}$.

Es posible señalar el desplazamiento experimentado como proceso político, si bien se ha orquestado con cierta sutilidad. Una parte del proceso político aplica métodos tradicionales en la planificación para garantizar la rentabilidad de la inversión, como permitir el cambio de uso del mercado y dotar con legalidad los permisos para aumentar las alturas permitidas en las áreas colindantes (caso del Abasto). En San Telmo, el proceso político se centró en los planes de renovación municipales, mientras que en La Boca el estímulo proviene de exenciones fiscales de las inversiones inmobiliarias que incluyen usos culturales, con el fin de perseguir atraer diseñadores, artistas y otros pioneros de la gentrificación ${ }^{34}$. Además, los tres casos tienen en común la extracción de valor del patrimonio intangible que es el Tango. En el caso del Abasto implica la apropiación económica de una marca, mediante el marketing en honor de Carlos Gardel, histórica

33 Herzer, Di Virgilio y Rodríguez, 2015.

34 Herzer y Gil y de Anso, 2012. areas $^{32}$. In San Telmo, the process is of a later date and included a commercial reorientation of the neighbourhood, through the mushrooming of cultural institutions, theatres, libraries, restaurants and concert-cafés, all closely related to Tango culture. This process also involved the transformation of the real estate market. Today, San Telmo is the ideal place for the provision of short or mid-term tourism accommodation. Finally, La Boca witnessed the construction of a series of loft apartment buildings in an attempt to attract artists. Likewise, there has been some kind of material violence in the form of forced eviction, such as fire (caused by "officially" unknown and ignored reasons) and other forced relocation ${ }^{33}$.

The experimented displacement has been orchestrated in a very subtle way as a political process. To some degree, traditional planning methods were applied to guarantee the profit of investments. This is the case in the Abasto area, where legislative changes enabled the new use for the abandoned market, as well as higher buildings in the surrounding area. In San Telmo, this political process focused on municipal renovation plans; as for La Boca, the

32 Carman, 2011; Centner, 2012

33 Herzer, Di Virgilio and Rodríguez, 2015. 
estrella de Tango ${ }^{35}$. Las estrategias en San Telmo y La Boca están directamente relacionadas con los corredores culturales en diálogo con el Tango, con el Caminito (La Boca) como centro neurálgico de la actividad turística en el barrio. Además, se aprecia la instalación de instituciones culturales estatales que fomentan la transformación incipiente y "ponen en el mapa cultural" a los espacios en disputa.

En términos materiales, se experimenta un cambio en la composición social de los tres barrios que si bien es lenta, avanza y desplaza permanentemente a habitantes. Si se plantea la cuestión simbólica, consta que las estrategias lograron también transformar algunos de los usos del espacio e implementar la hegemonía de actividades que se relacionan con el turismo. En este sentido, se trata de una desposesión de la cultura popular que implica procesos de desplazamiento. Estos se relacionan intrínsecamente con los circuitos de valorización y las formas de regulación de conflictos subliminales, generando dos tipos de violencia simbólica, (i) la violencia turística y (ii) la violencia cultural. La implementación de nuevas estéticas en relación con la apropiación externa del "espectáculo" del patrimonio cultural se puede percibir como una estrategia que delimita una esfera de alteridad, generando violencias simbólicas por la mercantilización de unos (¿hipotéticos?) activos culturales del

Carman, 2006. stimulus came in the form of tax exemptions for cultural-oriented real estate investment in order to attract designers, artists and other processes of gentrification ${ }^{34}$. These three cases share the valuation of Tango and its intangible heritage. In the case of Abasto there is the economic appropriation of a brand through the marketing of items associated with Tango legend Carlos Gardel ${ }^{35}$. The strategies designed in the cases of San Telmo and La Boca are directly related to Tango routes such as Caminito (La Boca), which is a focal point for tourist activity. Likewise, it is possible to observe the creation of Stateowned cultural institutions intended to promote this emerging transformation and place these disputed spaces on the cultural agenda.

In material terms, there is an ongoing change in the social composition of these three neighborhoods which, though slow, is constantly progressing and permanently displacing dwellers. In symbolic terms, these strategies modified the use of space and contributed to the predominance of tourist-related activities. This process can be referred to as a dispossession of popular culture that involves different displacement processes that are closely related to the capital circuits

34 Herzer y Gil and de Anso, 2012.

35 Carman, 2006. 
barrio. Se ha visto la capacidad de lograr re-articular material y simbólicamente el espacio público, provocando a su vez el desplazamiento parcial de subjetividades populares, así como una serie de disputas que van desde el terreno psicológicosocial al material y legal.

\section{DESPLAZAMIENTO POR DESPOSESIÓN DE LOS DERECHOS DE CIUDADANÍA | RÍO DE JANEIRO}

Río de Janeiro es un caso único de reconfiguración urbanística a largo plazo que se promueve mediante un mecanismo central que es la expansión del mercado capitalista hacia espacios de organización social, económica y territorial que previamente fueron estructuradas por procesos alternativos de acumulación. A la vez es ejemplo destacado de un tipo de desplazamiento que ocurre mediante la desposesión de los derechos de ciudadanía. Para comprender mejor los procesos materiales, la morfología y geografía social de la ciudad han de ser tenidos en cuenta, de manera especial la extraordinaria disparidad de ingresos entre las capas más ricas y pobres de la sociedad. Como expresión física de ello, cabe resaltar que muchas favelas están localizadas en vecindad de los lugares que mayor valor de suelo tienen, como por ejemplo en los morros con vista a las playas ${ }^{36}$. En las áreas céntricas, más del 40 por ciento de la población vive en favelas, y esto significa que su cultura popular es parte of valuation and the regulation of subliminal conflicts, thus generating two types of symbolic violence, (i) tourist violence and (ii) cultural violence. The implementation of new aesthetics associated with the external appropriation of cultural heritage can be perceived as a strategy that generates a sense of otherness and symbolic violence as the result of the commodification of (hypothetical) cultural assets of a given population. Such a strategy has reconfigured the public space in material and symbolic terms, thus forcing the partial displacement of popular subjectivities and generating a series of disputes ranging from a psychological and social field to the material and legal terrain.

\section{DISPLACEMENT BY DISPOSSESSION OF CITIZENSHIP RIGHTS | RIO DE JANEIRO}

Rio de Janeiro is a unique case where long-term urban reconfiguration is promoted through the expansion of the capitalist markets into spaces of social, economic and territorial organization which were previously structured by alternative accumulative processes. This is also an example of a type of displacement triggered by the dispossession of citizenship rights. In order to better understand the material processes, 
normalizada de la vida urbana cotidiana ${ }^{37}$, mucho más que en otras ciudades que presentan pautas de segregación diferentes.

La relación entre ciudad formal e informal se encuentra en el centro del desplazamiento como proceso material. Sin embargo, requiere de un considerable apoyo por las políticas públicas que en caso de Río de Janeiro consisten en implementar grandes proyectos de renovación urbana, aplicar estrategias extremas de securitización y apostar por la celebración de eventos internacionales (deportivos) para articular mecanismos que mitiguen un continuo "estado de excepción"38. Tales mecanismos introducen nuevos modelos de ciudadanía, así como un régimen autoritario, empresarial y planificador que niega a los habitantes de las favelas el espacio político de ciudadano, e incluso les despoja en algunos casos de los derechos de propiedad. Cuatro estrategias entrelazadas se han ejecutado: (1) inversión municipal en la "regeneración" de las favelas (programas como Favela Bairro, Programa de Aceleração do Crescimento y, recientemente, Morar Carioca); (2) un desalojo selectivo de habitantes de favelas e incluso de comunidades enteras si se interponen en el camino de mega-eventos, como es el caso de Aldeia Maracanã y Vila Autódromo; (3) la reubicación de habitantes en complejos de

37 Vargas, 2013.

38 Sánchez y Broudehoux, 2013. particular attention should be given to the morphology and social geography of the city, as well as the extraordinarily high income disparity between the rich and the poor. As a material expression of this segregation, it should be taken into account that many favelas are located close to the places with the highest land values of the city, such as some of the "morros" (hills) with beach view ${ }^{36}$. In central areas, more than 40 percent of the population lives in favelas; this implies that popular culture is a common feature of daily urban life $e^{37}$, which is in contrast with the situation of other cities with different segregation patterns.

The relation between the formal and the informal city is at the very heart of the displacement as a material process. However, it requires a considerable support by public policies which, in the case of Rio de Janeiro, consist in the implementation of major urban renovation projects, extreme security strategies and the organization of international (sports) events; the idea here is to create mechanisms and mitigate a permanent "state of exception"38. These mechanisms involve new models of citizenship and an authoritarian, business-oriented 
vivienda social que están situados en la periferia de la ciudad (a través del programa federal Minha Casa, Minha Vida); y (4) la "pacificación" de las favelas por las Unidades de Policía Pacificadora, un cuerpo de policía paramilitar que desde 2008 ha supuestamente "liberado" varias docenas de favelas del tráfico de drogas, aplicando una violencia extrema a través de una ocupación cuasi-militar del territorio. En estas zonas, se han empleado desde entonces regímenes excepcionales de ciudadanía que implican importantes restricciones de los derechos civiles $^{39}$. Cabe señalar que las fuerzas policiales han sido repetidamente acusadas de violencia severa, y de producir aproximadamente 1.000 homicidios anuales ${ }^{40}$.

Las cuatro estrategias no son meramente un proceso político; nos relacionan también con el desplazamiento como proceso simbólico, ya que más allá de la violencia material, expresan destacadas violencias simbólicas y psicológicas contra los habitantes. Las grandes transformaciones de la estructura social, material y política buscan regular la conducta de las partes no deseadas de la población y relegarlos a un lugar que a la vez es material y simbólicamente alejado de las vistas de las clases medias y altas. En el caso de la comunidad de Vila Autódromo, lugar en el que a los habitantes

39 Freeman, 2014.

40 Comitê Popular da Copa e das Olimpíadas do Rio de Janeiro, 2014. planning regime that deprives favela inhabitants from their citizenship rights and dispossesses in some cases from their right to property. In this context, four interrelated strategies have been implemented: (1) municipal programs for the "regeneration" of favelas (Favela Bairro, Programa de Aceleração do Crescimento and Morar Carioca); (2) selective eviction of favela inhabitants and even entire communities in case that they stand in the way of mega events - as in the case of Aldeia Maracanã and Vila Autódromo; (3) the relocation of dwellers to social housing located in the periphery area of the city (Minha Casa, Minha Vida federal program); and (4) the role of the Pacifying Police Unit, a paramilitary force whose aim is to "eradicate" drug trafficking from favelas -such a task has been carried out since 2008 through the use of extreme violence and the military-like occupation of territory. The establishment of control goes hand in hand with exceptional citizenship regimes, and it has involved serious restrictions to civil rights ${ }^{39}$. It is worth pointing out that police forces have been repeatedly accused of using severe violence and killing about 1,000 favela dwellers every year ${ }^{40}$.

\footnotetext{
39 Freeman, 2014.

40 Comitê Popular da Copa e das Olimpíadas do Rio de Janeiro, 2014.
} 
se les otorgaron los títulos legales de usufructo de los terrenos, los vecinos han sido acusados por parte de las autoridades públicas de "daño estético y visual”41, devaluando así simbólicamente en el discurso público la autoconstrucción como método legítimo de construcción de hábitat. Estos argumentos no van en vano, porque construyen la legitimación simbólica para expulsar luego materialmente. Además, el caso de Vila Autódromo nos refiere también a las múltiples estrategias de acoso psicológico que el Estado aplica y que han logrado separar familias y enfrentar vecinos, con el fin de destruir una comunidad que decidió luchar por su derecho a permanecer en su lugar. Detrás de ello, se observa sin embargo un fondo de tinte racial, ya que la aplicación de excepciones en los regímenes de ciudadanía para forzar en términos prácticos, simbólicos y psicológicos la expulsión de habitantes se concentra en espacios y comunidades muy concretas.

\section{DESPLAZAMIENTO POR LA DESPOSESIÓN DE LA RENTA DEL SUELO | SANTIAGO DE CHILE}

Santiago de Chile puede definirse como un ejemplo muy específico de retorno del capital al centro de la ciudad, cuyos procesos de desposesión se pueden tipificar como desplazamiento de la renta

41 Cita de una entrevista personal, recogida en el documental EU FICO, disponible en línea: https://vimeo.com/106485221.
All of the above strategies are not exclusively related to political processes but also to symbolic displacement processes since, apart from being subject to material violence, favela dwellers are victims of symbolic and psychological violence. These major social, material and political changes aim at regulating the behavior of the undesired population and relocating them to a materially and symbolically distant space, away from middle and upper classes. In the case of Vila Autódromo, local dwellers -who were legally authorized to use this land- have been accused by authorities of inflicting "visual and esthetic harm"41 to the area, an accusation that symbolically devaluates in public discourse the self-construction as a legitimate way of producing habitat. These arguments are intended to create a symbolically legitimate reason to materially eradicate these groups. This case also reveals the different psychological harassment strategies used by the State to divide families, generate disputes among neighbors and, ultimately, destroy a community that defended its right to inhabit this area. However, there may be some racial motivations behind the implementation of these measures, especially as the application of exceptional regimes of citizenship targets in

41 Quote taken from a personal interview; EU FICO, available at https://vimeo.com/106485221.

ARTICLE: Gentrification-Displacement-Dispossession: Key Urban Processes in Latin American cities / Michael Janoschka 
del suelo ${ }^{42}$. el caso de Santiago es interesante desde varias perspectivas: en una sola década (de 2002 a 2012), se invirtió el modelo de expansión, del centrifugal a uno que se centra principalmente en la ciudad consolidada. Por ejemplo, en el municipio de Santiago se dobló el stock inmobiliario total en tan solo una década ${ }^{43}$, y desde 2006, las 11 comunas centrales y peri-centrales del área metropolitana han concentrado tres quintos de los permisos de construcción ${ }^{44}$. Parte de esta inversión residencial fue efectuada por universidades privadas, que han sido actores importantes en el mercado inmobiliario $^{45}$. Pensando en los mecanismos de desplazamiento, cabe señalar que se documentó una creciente acumulación de la renta potencial del suelo por parte de un reducido grupo de grandes inversores ${ }^{46}$. Es decir, se capitaliza de forma monopolista por inversores a gran escala, desposeyendo a los pequeños propietarios de las alzas potenciales de renta del suelo que han tenido lugar, muchos de ellos sin capital necesario para efectuar ninguna inversión. Además, debido al alza exponencial de los precios de las viviendas, muchos arrendatarios fueron desplazados.

El proceso guarda una estrecha vinculación con las políticas públicas. Por ejemplo, en lo que se

42 Término adaptado de López Morales, 2011.

43 Pasando de las 76.000 unidades a 148.850; Figueroa, 2013.

44 López, Gasic y Corvalán, 2012.

45 Borsdorf e Hidalgo, 2013.

46 López, 2011. practical, symbolic and psychological terms the expulsion of inhabitants of only very specific spaces and local communities.

\section{DISPLACEMENT BY GROUND RENT DISPOSSESSION | SANTIAGO}

Santiago de Chile can be defined as a specific example of the return of capital to the central areas of a city, whose dispossession processes may be referred to as displacement of ground rent ${ }^{42}$. Santiago is an interesting case for a variety of reasons: within only one decade (2002-2012), the city experienced a dramatic transformation of its growth model-from a centrifugal model to an approach that concentrated on the restructuring of the consolidated areas of the city. For instance, the Municipality of Santiago doubled its real estate stock within a ten-year period ${ }^{43}$ and, since 2006, the 11 central and peri-central municipalities have accounted for three-fifths of construction permits ${ }^{44}$. A part of this residential development stems from private universities, which have been important actors on the real estate market ${ }^{45}$. Regarding the mechanisms of

\footnotetext{
42 Term adapted from López Morales, 2001.

43 From 76,000 to 148,850 units; Figueroa, 2013.

44 López, Gasic and Corvalán, 2012.

45 Borsdorf and Hidalgo, 2013.
} 
refiere al desarrollo de programas de vivienda social que proporcionan subsidios públicos para la adquisición de terrenos y viviendas. Las medidas establecieron un modelo mercantilizado de vivienda social que aplica estrictamente los criterios económicos para determinar el lugar de residencia. Este modelo implica una profunda reorganización social y espacial del área metropolitana, por el consiguiente desplazamiento de familias de menores recursos hacia complejos de vivienda en la periferia. La "vuelta al centro" es igualmente un ejemplo estimulante de cómo la planificación urbana empresarial privilegia a la inversión privada en una economía liberal. El pago de un subsidio en el valor de compra de viviendas que están destinadas a ocupantes con una capacidad adquisitiva correspondiente a clases medias emergentes o profesionales jóvenes, etc., permite la emancipación de ciertos hogares y crea un mercado residencial específico, muy prominente en la tipología de viviendas que se han ido construyendo ${ }^{47}$. Además la liberalización de los procesos de planificación urbana, especialmente la permisividad de los permisos de construcción que permiten alturas de hasta 35 pisos, ha promovido la enorme densificación de la superficie construida. Sin embargo, el Estado no se pronuncia cuando se cuestiona la idoneidad urbanística de esas propiedades residenciales.

47 López, 2013. displacement, a growing accumulation of the potential ground rent by a small group of large investors has been documented ${ }^{46}$. In other words, land is monopolized by these investors, thus dispossessing small proprietors -most of them lacking investment capital- of the potential increase in land values. Likewise, a considerable number of tenants have been displaced from central areas as the result of the exponential increase in housing prices.

This process is closely related to public policies, especially when it comes to social housing programs that grant public subsidies for the purchase of land and dwellings. These measures laid the foundations for the commodification of social housing, which is strictly based on the use of economic criteria to determine the place of residence. This model involves the social and spatial reorganization of the metropolitan area and the subsequent displacement of lower-income families to housing developments located in periurban areas. The "back-to-the-center" trend is thus an example of how a business-oriented urban planning favors private investment within a liberal economy. The allocation of public subsidies to buy apartments aimed at attracting dwellers with a purchase power that corresponds,

46 López, 2011. 
Planteándose el desplazamiento como proceso simbólico, cabe destacar que en Santiago de Chile éste depende del deterioro y abandono de viviendas existentes, resultado de la "destrucción creativa" previamente descrita. La reproducción capitalista genera nuevos bienes que posibilitan de forma eficaz los procesos de acumulación. Con el efectivo apoyo de un Estado que paradójicamente "regula" la ausencia del marco de su actuación, la densificación de la ciudad desemboca en una ocupación territorial irregular y abrupta que produce violencias arquitectónicas de mayor índole simbólica. Teniendo en cuenta el principio inversor del máximo beneficio posible con la mínima inversión necesaria como un ejercicio práctico de economías ultra-neoliberales, la ejecución financiera de esta estrategia de inversión genera significativas violencias simbólicas de un urbanismo que a la vez tiene efectos psicológicos en la población y provoca el desplazamiento de subjetividades populares.

\section{DESPLAZAMIENTO POR DESPOSESIÓN DE LAS PLUSVALÍAS DE LA INTERVENCIÓN PÚBLICA | QUITO}

La ciudad de Quito implica la estilización de un tipo de desplazamiento que se relaciona con los cambios sociales que se han originado en un país que tuvo una importante rearticulación de su modelo organizativo, a partir de la elaboración de amongst others, to new middle-classes or young professional. It contributes to the emancipation of households by creating a specific residential market that is very prominent for the typology of newly constructed apartments ${ }^{47}$. Likewise, the liberalization of planning procedures and especially the permissive legislation on the maximum altitude of buildings, has been promoting the vast densification of the central areas, with apartment tower rising up to 35 floors. However, the State remains silent when it comes to the suitability of these dwellings in terms of urbanity.

When understood as a symbolic process, displacement depends on the deterioration and abandonment of existent dwellings resulting from the "creative destruction" described above. Capitalist reproduction generates new goods that facilitate efficiently accumulation processes. Likewise, with the support of a State that paradoxically "regulates" the absence of legislative frameworks, densification evolves into an irregular territorial occupation, thus generating symbolic architectural violence. By combining the principle of maximum benefit with minimum investment as an exercise of ultraneoliberal economies, it is possible to observe

47 López, 2013. 
una Carta Magna que transforma algunas de las relaciones concretas entre capital y sociedad. Sin embargo, la constitución de unas nuevas consciencias políticas y la gran expansión de las políticas públicas que tuvo lugar en la última década no implica evitar los procesos de desplazamiento. En este sentido, Quito puede tipificarse como caso predilecto del desplazamiento por la desposesión de las plusvalías de la intervención pública. Lo que se refiere a los procesos de desplazamiento material que se observa en una de las dos parroquias de estudio, Cumbayá, está íntimamente relacionado con la expansión suburbana de la ciudad y el desbordamiento del valle central a partir de los nuevos proyectos inmobiliarios que ocurrieron desde la dolarización ${ }^{48}$. Estos proyectos se asientan sobre antiguas zonas industriales o terrenos agrícolas, por lo cual implican también una rearticulación en la vocación de los terrenos afectados. Como resultado, se implementaron nuevos negocios inmobiliarios, en general en el marco de fraccionamientos cerrados, con alto grado de seguridad y vigilancia que permiten poca interacción entre los residentes de diferentes urbanizaciones. Y el tejido comercial se modificó también marcadamente, con la proliferación de conjuntos comerciales de gran superficie. Ambos procesos implican el desplazamiento material de actividades relacionadas con la vida tradicional en la parroquia, de mayor

48 Durán, Martí y Mérida, 2016. the emergence of severe symbolic violence of a kind of urbanism that psychologically affects the population, provoking the displacement of popular subjectivities.

\section{DISPLACEMENT BY THE DISPOSSESSION OF BENEFITS OBTAINED FROM PUBLIC INTERVENTIONS | QUITO}

Quito is associated with a type of displacement related to the social and organizational changes generated by the adoption of a new Constitution that clearly modified the relationships between capital and society. However, the emergence of new political subjectivities and the expansion of public policies over the last decade do not mean that there has been no displacement process. In this sense, Quito can be classified as an exemplary case of displacement by the dispossession of benefits obtained from public interventions. As for material displacement, the experience of Cumbaya is closely related to suburban expansion through real estate projects that expanded since the country adopted the US dollar as its currency ${ }^{48}$. These projects are located in former industrial but especially rural areas, provoking a structural territorial reorganization. As a result, new real estate

48 Durán, Martí and Mérida, 2016. 
impregnación agraria y basada en prácticas indígenas. En este sentido, lo que se puede observar es una confrontación directa de dos formas de vida marcadamente diferenciadas, de dos subjetividades con poca interacción real.

La transformación es resultado directo de la actuación pública, destacándose dos procesos superpuestos sin los cuales los procesos materiales de desplazamiento no se podrían comprender. Por un lado, se trata de la reforma agraria que expropió parte de una finca en la parroquia de Cumbayá, y a la vez logró asentar y formalizar los asentamientos huasipungueros (forma de tenencia originaria de la tierra). Por otro lado, se trata de la inversión pública en grandes obras de infraestructura vial que se relacionan con la construcción del nuevo aeropuerto internacional en la zona, inaugurado en $2012^{49}$. Este escenario crea plusvalías y aumentos del valor de la tierra que, sin embargo, están explotados por las iniciativas privadas de desarrollo inmobiliario que han ido surgiendo posteriormente.

Como en los demás casos, podemos observar también en el caso de Cumbayá un desplazamiento que va más allá del ensamblaje de los procesos materiales y políticos y que implica también aspectos simbólicos. Por ejemplo, se trata de la confrontación de diferentes formas de vida, entre una población tradicional con raíces indígenas y habitantes

49 Bayón, 2016. projects mushroomed, mainly in the form of heavily securitized gated communities that do not permit any meaningful social interactions across fences. Additionally, also the commercial infrastructure has undergone a major transformation, with the proliferation of large shopping centers. Both processes involved the material displacement of everyday-life activities in a county previously characterized indigenous and agrarian practices. Therefore, it is possible to observe a direct confrontation between two distinctly different forms of life and subjectivities that have little interaction with each other.

This transformation is the direct consequence of public action; in this sense there are two overlapping phenomena that are essential to understand material displacement. On the one hand there is the agrarian reform, which involved the expropriation of land and the subsequent establishment and formalization of "huasipungos" (an original indigenous land tenure system.) On the other hand, attention should be given to public investment in road infrastructure as part of the construction of a new international airport in the area -which opened in $2012^{49}$. This scenario generated added value and increased the value of land; however,

49 Bayón, 2016. 
de clase media-alta y alta radicados en conjuntos cerrados, que disputan en términos simbólicos por la apropiación del espacio. A los factores estructurales de nueva ocupación de la tierra, que redujeron drásticamente las prácticas agrícolas en la parroquia, se suman las restricciones impuestas por el municipio, representando el espacio simbólico de acuerdo a las subjetividades de las clases altas instaladas. Esto se refiere, por ejemplo, a la pugna por lo que es permitido y prohibido mediante las ordenanzas municipales. Cabe señalar que los planes de ordenación han ido restringiendo sucesivamente las prácticas tradicionales de ocupación del espacio público (como en las fiestas comunitarias) y privado (prohibición de cría de animales). Además, privilegian el uso del transporte privado frente a las necesidades de comunicación de los antiguos pobladores ${ }^{50}$. Esta situación implementa un dispositivo de desposesión que traslada las plusvalías generadas por la actividad y la inversión pública hacia los nuevos inversores. Desvaloriza de forma simbólica las costumbres populares y las prácticas tradicionales arraigadas en el territorio, aplicando una violencia simbólica de la "modernidad" establecida como proceso normalizador que se manifiesta en la transformación territorial.

Durán, Martí y Mérida, 2016. these benefits are currently being exploited by private real estate companies as the result of the development of private real estate development in the area.

As in previous cases, the situation of Cumbayá also reveals a form of displacement that goes beyond material and political processes and involves symbolic aspects. For instance, there is the confrontation between opposite lifestyles represented by a traditional indigenous community and upper-middle/upper class households who live in gated communities; such a dispute is related also to the symbolic appropriation of space. While the practice of agriculture has reduced drastically in the area, the structural reorientation of the land tenure and use has also political consequences. For instance, the local government, increasingly dominated by the new dwellers, has been successively applying restrictions to traditional uses of both public and private space, prohibiting some substantial 'ingredients' of the traditional community celebrations, and drastically reducing permits to grow animals in the municipality. Such a strategy symbolically recomposes the possibility of spatial practices, following clearly the subjectivities of the new upper-class dwellers. 


\section{Desplazamiento como acumulación por desposesión del hábitat . Reflexiones críticas en torno al derecho a la ciudad}

Lo anteriormente expuesto ha proporcionado una mejor comprensión de los mecanismos subyacentes en los procesos de desplazamiento y acumulación por desposesión del hábitat, señalando su carácter polifacético a partir de los ejemplos paradigmáticos de cinco ciudades latinoamericanas. Se ha podido comprobar en cada uno de los casos cuáles son las fuerzas detrás de los procesos de desplazamiento y cómo actúan. Para este análisis, la diferenciación del desplazamiento como proceso material, político, simbólico y psicológico ha sido útil, ya que ha permitido identificar diversos mecanismos de desposesión cuyo denominador común es el intento de extraer lo que antes se encontraba en los márgenes de los mercados capitalistas. Si entendemos la acumulación urbana de capital como una forma espacial del capitalismo en busca de nuevos espacios y lugares que no hayan sido aún mercantilizados, la transformación de los entornos populares y de su particular morfología urbana puede considerarse como uno de los objetivos clave. Como se ha visto en los diferentes
Likewise, different initiatives favor the use of private transport, thus affecting the access needs of original dwellers of public transport ${ }^{50}$. This situation activates a dispositive of dispossession that withdraws the benefits generated by public investment from the original inhabitants to the new investors and dwellers. Additionally, traditional and territorially rooted cultural practices become symbolically 'devaluated : In other words, the normalizing processes which are generated by this introduction of "modernity" result both into territorial transformation and symbolic violence.

\section{Displacement as Accumulation of Habitat Dispossession - Critical Reflections on the Right to the City}

This article has provided thus far a deeper insights into the underlying mechanisms for displacement and the process of accumulation of habitat dispossession by revealing their multifaceted nature according to the paradigmatic experiences of five Latin American cities. It has been possible to

50 Durán, Martí and Mérida, 2016. 
ejemplos, la introducción de nuevas relaciones de mercado produce desplazamiento, pero no necesariamente significa la expulsión material inmediata de determinados lugares.

Por lo tanto, la acumulación por desposesión del hábitat como lente analítica permite comprender los principios de reestructuración de las ciudades latinoamericanas desde una perspectiva holística. En este sentido, el desplazamiento es un mecanismo central de la desposesión que implica la rearticulación urbana reciente, y se manifiesta en cuatro dimensiones: la material, política, simbólica y psicológica. Por ende, cabe señalar que la exclusión simbólica y el desplazamiento de las perspectivas de las clases populares son precondiciones básicas para lograr su expulsión material del espacio. Está relacionada intrínsecamente con las jerarquías sociales existentes, así como con estereotipos o estigmas de índole étnica y racial. En último término, el desplazamiento reestablece y exacerba esas jerarquías, contrarrestando las políticas sociales que habían sido aplicadas supuestamente para reducir las fronteras invisibles en la estructuración de clase y del racismo. Tales operaciones pueden ocurrir consciente o inconscientemente, y aplican diferentes tipos de violencia. Pero siempre generan beneficios simbólicos que se apartan de la acumulación de diferentes tipos de capital (simbólico, cultural, económico) por parte de aquellos sujetos que sean capaces de definir, gobernar y dominar espacios corroborate the guiding forces behind displacement processes and understand how they operate in each of the cases under review. For the purposes of this analysis, the differentiation of displacement as material, political, symbolic and psychological processes has proved being useful since it allow us to identify new mechanisms of dispossession that share the intention of extracting those aspects that used to be at the margins of capitalist markets. By understanding the urban accumulation of capital as a spatial form of capitalism intended to discover new spaces and places that still remain free from commodification, the transformation of popular environments and their particular urban morphology is a key objective that should be accomplished. According to the different concepts exposed through this research, the introduction of new market-oriented relationships produces displacement; however, this does not necessarily mean the immediate material eviction from specific places.

Therefore, the analytic lens of accumulation by habitat dispossession allows us to understand the restructuration principles of Latin American cities from a holistic perspective. In this sense, displacement emerges as a central mechanism of dispossession in the course of recent urban reconfiguration through four different dimensions: material, political, symbolic and psychological. 
y lugares ${ }^{51}$. Este argumento se relaciona directamente con los métodos de reproducción social de las clases dominantes y los discursos existentes que estructuran las posibles prácticas, inclinaciones del habitus y posiciones en la esfera social. Las relaciones invisibles de poder definen los modos en los que el desplazamiento actúa, por ejemplo escondiendo ciertas prácticas sociales y culturales mientras otras se criminalizan. Tales estrategias hacen uso de violencia tanto simbólica como física para desplazar a los no deseados y usuarios de los espacios urbanos concretos que se consideran elementales para la revalorización.

Sin embargo, la informalidad en las ciudades latinoamericanas ha generado también terrenos específicos para el sustento individual y colectivo, la auto-organización y procesos políticos que van más allá del Estado y construyen una especie de contrapoder. Como consecuencia, se internalizaron diferentes prácticas, tanto conscientes como inconscientes, que podrían impedir que las micro-políticas capitalistas penetraran a fondo en el seno de la sociedad, creando formas alternativas y contra-hegemónicas de producir, vivir y apropiarse de la ciudad ${ }^{52}$. Tal organización colectiva de redes de solidaridad supone un serio escollo, hasta el día de hoy, para una implementación rápida, fácil y sin contratiempos de las políticas de desplaza-

51 Janoschka y Sequera, 2016.

52 Zibechi, 2008.
Therefore, it is worth stressing that symbolic exclusion and the displacement of popular classes are basic requirements for the achievement of material expulsion. This is closely related to current social hierarchies and ethnic and racial stereotypes and stigmas. Finally, displacement restores and reinforces these hierarchies, as well as thus countering social policies that supposedly intended to reduce the invisible boundaries of class structuration and racism. These operations may be consciously or unconsciously implemented and involve different types of violence. However, they always generate symbolic benefits derived from the accumulation of different forms of capital (symbolic, cultural and economic) by those who are able to define, control and dominate spaces and places $^{51}$. This argument is directly related to the social reproduction of dominant classes and the discourses that structure possible practices, habitus dispositions and positions within the social sphere. Invisible power relations define the different ways of how displacement is enacted by hiding certain social and cultural practices and criminalizing others. These strategies use symbolic and physical violence to displace undesired individuals and users of specific urban spaces that are essential for the revaluation of space.

51 Janoschka and Sequera, 2016. 
miento. Y permite plantear unas alternativas que cuestionan, desde la organización popular, los mecanismos de construcción de la ciudad neoliberal. Si bien el derecho a la vivienda se ha visto crecientemente satisfecho en las ciudades de la región, el desplazamiento y los mecanismos de acumulación por desposesión del hábitat han empeorado la posibilidad de las clases populares de apropiarse de la centralidad de las ciudades. Es en este punto donde el presente artículo ha querido aportar una perspectiva analítica y conceptual acerca de algunos de los impedimentos existentes a que el Derecho a la Ciudad se cumpla no como discurso político, sino como práctica social.
However, the informal nature of Latin American cities has also given rise to the emergence of specific terrains for individual and collective support, self-organization and political processes that go beyond the State, thus constructing a type of counter-hegemonic power positions. This led to the internalization of conscious and unconscious practices that may prevent capitalist micro-policies from penetrating all spheres of society, generating alternative and counter-hegemonic ways of producing, living and appropriating the city ${ }^{52}$. Such a collective organization of solidarity networks has hampered the rapid and easy implementation of displacement policies and enabled the elaboration of alternatives that based on popular organization challenge the key mechanisms of the neoliberal city. While the right to housing has been increasingly satisfied in Latin American cities, displacement and the accumulation by habitat dispossession have seriously compromised the chances of popular classes to appropriate the centrality of cities. The nuanced understanding provided in this article about the interrelationship of the different dimensions of this phenomenon may be considered as the key contribution, chiefly by developing analytical and conceptual perspectives about factors that prevent the Right to the City be transformed from a political discourse into a social practice on the ground.

52 Zibechi, 2008. 


\section{Bibliografía}

AALBERS, Manuel. How Do Mortgage Lenders Influence Neighbourhood Dynamics? Redlining and Predatory Lending. En: VAN HAM, Maarten, ed.; MANLEY, David, ed.; BAILEY, Nick, ed.; SIMPSON, Ludi, ed. y MACLENNAN, Duncan, ed. Understanding Neighbourhood Dynamics. New Insights for Neighbourhood Effects Research. Dordrecht, Springer. 2013. p 63-86.

APAOLAZA, Ricardo; BLANC0, Jorge; LERENA Natalia; LÓPEZ MORALES, Ernesto; LUKAS, Michael y RIVERA, Maite. Transporte, desigualdad social y capital espacial: análisis comparativo entre Buenos Aires y Santiago de Chile. Íconos Revista de Ciencias Sociales. (56): 19-41, 2016. DOI 10.17141/ iconos.56.2016.2148.

ATKINSON, Rowland. Losing One's Place: Narratives of Neighbourhood Change, Market Injustice and Symbolic Displacement. Housing, Theory and Society. 32(4): 373-388, 2015. DOI 10.1080/14036096.2015.1053980.

BAYÓN JIMÉNEZ, Manuel. Comunidades rurubanas de Quito: entre el empresarialismo y el derecho a la ciudad. Íconos Revista de Ciencias Sociales. (56): 103-122, 2016. DOI 10.17141/ iconos.56.2016.2068.

BECKER, Anne y MÜLLER, Markus-Michael. The securitization of urban space and the "rescue" of downtown Mexico City: Vision and practice. Latin American Perspectives. 40(2):77-94, 2013. DOI $10.1177 / 0094582 \mathrm{X} 12467762$.
BETANCUR John J. Gentrification in Latin America: Overview and Critical Analysis. Urban Studies Research. (2014), art. 986961, 2014. DOI $10.1155 / 2014 / 986961$.

BLANCO, Jorge y APAOLAZA, Ricardo. Políticas y geografías del desplazamiento. Contextos y usos conceptuales para el debate sobre gentrificación. Revista INVI. 31(88), 2016.

BLANCO, Jorge; BOSOER, Luciana y APAOLAZA, Ricardo. Gentrificación, movilidad y transporte: aproximaciones conceptuales y ejes de indagación. Revista de Geografía Norte Grande. (58): 41-53, 2014. DOI 10.4067/S0718-34022014000200003.

BORSDORF, Axel e HIDALGO, Rodrigo. Revitalization and tugurization in the historical centre of Santiago de Chile. Cities. 31: 96-104, 2013. DOI 10.1016/j.cities.2012.09.005

CARMAN, María. El proceso de ennoblecimiento y la salida negociada de los innobles en Buenos Aires. Cadernos Metrópole. 13(25): 257-278, 2011.

--- Las trampas de la cultura. Los "intrusos" y los nuevos usos del barrio de Gardel. Paidós, Buenos Aires. 2006.

CASGRAIN, Antoine y JANOSCHKA, Michael. Gentrificación y resistencia en las ciudades latinoamericanas: El ejemplo de Santiago de Chile. Andamios - Revista de investigación social. 10(22): 19-44, mayo 2013.

CENTNER, Ryan. Moving away, moving onward: displacement pressures and divergent neighborhood 
politics in Buenos Aires. Environment and Planning A. 44(11): 2555-2573, 2012. DOI 10.1068/ a 44440

CóCOLA GANT, Agustin; DURÁN, Gustavo y JANOSCHKA, Michael. La ciudad del siglo XXI: Políticas públicas urbanas, desplazamientos y contestaciones. Íconos Revista de Ciencias Sociales. (56), septiembre 2016. DOI 10.17141/iconos.56.2016.2351.

COMITÊ Popular da Copa e das Olimpíadas do Rio de Janeiro. Megaeventos e Violações dos Direitos Humanos no Rio de Janeiro. [En línea]. Comitê Popular da Copa e Olimpíadas do Rio de Janeiro. Junio 2014. [Fecha de consulta: 26 julio 2015]. Disponible en: https://comitepopulario.files.wordpress. com/2014/06/dossiecomiterio2014_web.pdf.

CROSSA, Veronica. Resisting the entrepreneurial city: Street vendors' struggle in Mexico City's historic center. International Journal of Urban and Regional Research. 33(1): 43-63, 2009. DOI 10.1111/j.1468-2427.2008.00823.x.

DAVIS, Diane E. Zero-tolerance policing, stealth real estate development, and the transformation of public space: Evidence from Mexico City. Latin American Perspectives. 40(2): 53-76, 2013. DOI 10.1177/0094582X12467761.

DELGADILLO, Víctor. Repoblamiento y recuperación del centro histórico de la ciudad de México, una acción pública híbrida, 2001-2006. Economía, Sociedad y Territorio. 8(28): 817-845, 2008.

DELGADILLO, Víctor. Selective modernization of Mexico City and its historic center. Gentrification without displacement? Urban Geography. 2016. DOI 10.1080/02723638.2015.1096114.

DELGADILLO, Víctor, coord.; DÍAZ, Ibán, coord. y SALINAS, Luis, coord. Perspectivas del estudio de la gentrificación en México y América Latina. México, Instituto de Geografía Universidad Nacional Autónoma de México. 2015.

DESMOND, Matthew. Eviction and the Reproduction of Urban Poverty. American Journal of Sociology. 118(1): 88-133, 2012. DOI 10.1086/666082.

DURÁN, Gustavo; MARTí, Marc y MERIDA, Juan. Crecimiento, segregación y mecanismos de desplazamiento en el periurbano de Quito. Íconos Revista de Ciencias Sociales. (56): 123-146, 2016. ISSN: 1390-8065. DOI 10.17141/iconos.56.2016.2150.

FIGUEROA, Angélica. Análisis y conclusiones resultados preliminares Censo 2012. [En línea]. Cámara Chilena de la Construcción. Marzo 2013. [Fecha de consulta: 22 julio 2015]. Disponible en: http:// www.cchc.cl/uploads/archivos/archivos/MinutaCTR-No-04-ANALISIS-Y-CONCLUSIONES-RESULTADOS-PRELIMINARES-CENSO-2012.pdf.

FREEMAN, James. Raising the flag over Rio de Janeiro's favelas: Citizenship and social control in the Olympic city. Journal of Latin American Geography. 13(1): 7-38, 2014. DOI 10.1353/lag.2014.0016.

GARCÍA HERRERA, L.; SMITH, Neil y MEJÍAS VERA, M. Gentrification, Displacement, and Tourism in Santa Cruz de Tenerife. Urban Geography. 28(3): 276-298, 2007. DOI 10.2747/0272-3638.28.3.276. 
GILLESPIE, Tom. Accumulation by urban dispossession: struggles over urban space in Accra, Ghana. Transactions of the Institute of British Geographers. 41(1): 66-77, 2016. DOI 10.1111/tran.12105.

GODFREY, Brian J. y ARGUINZONI, Olivia M. Regulating public space on the beachfronts of Rio de Janeiro. Geographical Review. 102(1): 17-34, 2012. DOI 10.1111/j.1931-0846.2012.00128.x.

HARTMANN, Chester W.; KEATING, Dennis y LEGATES, Richard. Displacement: How to Fight It. Berkeley, National Housing Law Project. 1982.

HARVEY, David. El nuevo imperialismo. Madrid, Akal. 2004.

HERZER, Hilda; DI VIRGILIO, Mercedes y RODRIGUEZ, Carla. Gentrification in Buenos Aires: global trends and local features. En: LEES, Loretta; SHIN, Hyun y LÓPEZ-MORALES, Ernesto. Global Gentrifications: Uneven Development and Displacement. Bristol, Policy Press. 2015. p. 199-222.

HERZER, Hilda y GIL Y DE ANSO, Laura. Introducción. En: HERZER, Hilda, comp. Barrios al sur. Renovación y pobreza en la ciudad de Buenos Aires. Buenos Aires, Café de las Ciudades. 2012.

HIDALGO, Rodrigo, ed. y JANOSCHKA, Michael, ed. La ciudad neoliberal: gentrificación y exclusión en Santiago de Chile, Buenos Aires, Ciudad de México y Madrid. Santiago de Chile, Pontificia Universidad Católica de Chile. 2014. Serie Geolibros
HODKINSON, Stuart y ESSEN, Chris. Grounding accumulation by dispossession in everyday life. The unjust geographies of urban regeneration under the Private Finance Initiative. International Journal of Law in the Built Environment. 7(1): 72-91, 2015. DOI 10.1108/IJLBE-01-2014-0007.

INZULZA, Jorge y GALLEGUILLOS, Ximena. Latino gentrificación y polarización: transformaciones socioespaciales en barrios pericentrales y periféricos de Santiago, Chile. Revista de Geografía Norte Grande. (58): 135-159, 2014. DOI 10.4067/ S0718-34022014000200008.

JANOSCHKA, Michael. El nuevo modelo de la ciudad latinoamericana: fragmentación y privatización. EURE. 28(85): 11-20, diciembre 2002. DOI 10.4067/S0250-71612002008500002.

JANOSCHKA, Michael y SEQUERA, Jorge. Gentrification in Latin America: addressing the politics and geographies of displacement. Urban Geography. 2016. DOI 10.1080/02723638.2015.1103995.

JANOSCHKA, Michael; SEQUERA, Jorge y SALINAS, Luis. Gentrification in Spain and Latin America a Critical Dialogue. International Journal of Urban and Regional Research. 38(4): 1234-1265, 2014.

LEES, Loretta. The geography of gentrification. Thinking through comparative urbanism. Progress in Human Geography. 38(2): 155-171, 2012. DOI 10.1177/0309132511412998

LÓPEZ MORALES, Ernesto. Gentrificación en Chile: aportes conceptuales y evidencias para una discusión necesaria. Revista de Geografía 
Norte Grande. (56): 31-52, 2013. DOI 10.4067/ S0718-34022013000300003.

--- Gentrification by ground rent dispossession: The shadows cast by large-scale urban renewal in Santiago de Chile. International Journal of Urban and Regional Research. 35(2): 330-357, 2011. DOI 10.1111/j.1468-2427.2010.00961.x.

LÓPEZ MORALES, Ernesto; GASIC KLETT, Ivo y CORVALÁN MEZA, Daniel. Urbanismo pro-empresarial en Chile: Políticas y planificación de la producción residencial en altura en el pericentro del Gran Santiago. Revista INVI. 27(76): 75-114, 2012. DOI 10.4067/S0718-83582012000300003.

MCFARLANE, Colin. The Comparative City: Knowledge, Learning, Urbanism. International Journal of Urban and Regional Research. 34(4): 725-742, 2010. DOI 10.1111/j.1468-2427.2010.00917.x.

MARCUSE, Peter. Gentrification, social justice and personal ethics. International Journal of Urban and Regional Research. 39(6): 1263-1269, 2015. DOI 10.1111/1468-2427.12319.

--- Gentrification, abandonment and displacement. Connection, cause and policy responses in New York City. [En línea]. Journal of urban and contemporary law. 28: 195-240, enero 1985. Disponible en: http://openscholarship.wustl.edu/ law_urbanlaw/vol28/issl/4.

MATTOS, Carlos de. Metropolización y suburbanización. EURE. 27(80): 5-8, 2001. DOI 10.4067/ S0250-71612001008000001

PATON, Kirsteen. Gentrification: a working-class perspective. London, Ashgate. 2014.
PECK, Jamie. Cities beyond Compare? Regional Studies. 49(1): 160-182, 2015. DOI 10.1080/00343404.2014.980801.

ROBINSON, Jennifer. Thinking cities through elsewhere. Comparative tactics for a more global urban studies. Progress in Human Geography. 40(1): 3-29, 2016. DOI 10.1177/0309132515598025.

SÁNCHEZ, Fernanda y BROUDEHOUX, Anne-Marie. Mega-events and urban regeneration in Rio de Janeiro: Planning in a state of emergency. International Journal of Urban Sustainable Development. 5(2): 132-153, 2013. DOI 10.1080/19463138.2013.839450.

SANTOS, Boaventura de Souza. Des-pensar para poder pensar. En: Descolonizar el saber, reinventar el poder. Montevideo, Ediciones Trilce, 2010. ISBN 978-956-00-0452-9.

SASSEN, Saskia. Expulsions: brutality and complexity in the global economy. Cambridge, Harvard University Press. 2014

SEQUERA, Jorge y JANOSCHKA, Michael. Gentrification dispositifs in the historic centre of Madrid: a re-consideration of urban governmentality and state-led urban reconfiguration. En: LEES, Loretta, ed.; SHIN, Hyun, ed. y LÓPEZ MORALES, Ernesto, ed. Global Gentrifications: Uneven Development and Displacement. Bristol, Policy Press. 2015. p. 375-394.

SHAW, Kate y HAGEMANS, Iris W. 'Gentrification Without Displacement' and the Consequent Loss of Place. Effects of Class Transition on Lowincome Residents of Secure Housing in Gentrifying Areas. International Journal of Urban and 
Regional Research. 39(2): 323-241, 2015. DOI 10.1111/1468-2427.12164.

SLATER, Tom. Missing Marcuse: On gentrification and displacement. City. 12 (2-3): 292-311, 2009. 10.1080/13604810902982250.

VARGAS, João H. Costa. Taking back the land: Police operations and sport megaevents in Rio de Janeiro. Souls: A Critical Journal of Black Politics, Culture, and Society. 15(4): 275-303, 2013. DOI 10.1080/10999949.2013.884445.

WALEY, Paul. Speaking gentrification in the languages of the Global East. Urban Studies. 53(3): 615-625, 2016. DOI 10.1177/0042098015615726.

ZIBECHI, Raúl. Territorios en resistencia: cartografía política de las periferias urbanas latinoamericanas. Buenos Aires, Lavaca. 2008. 